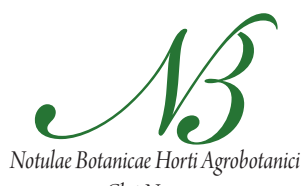

Cluj-Napoca

\title{
Stem and Crown Characteristics of Norway Spruce [Picea abies (L.) Karst] Populations from Romanian Carpathians
}

\author{
Marius BUDEANU' ${ }^{1}$ Neculae ŞOFLETEA2* \\ ${ }^{1}$ Forest Research and Management Institute, 13 Cloşca Street, 500040, Braşov, Romania; budeanumarius@yahoo.com \\ ${ }^{2}$ Transilvania University of Braşov, Department of Silviculture, Sirul Beethoven Street, nr. 1, \\ 500123, Braşov, Romania; nic.sofletea@unitbv.ro ( ${ }^{*}$ corresponding author)
}

\begin{abstract}
To establish the most important Norway spruce Romanian populations, open-pollinated progeny of ten plus trees originating from 33 seed stands mapped in the Romanian Carpathians have been evaluated for stem and crown characteristics at the age of 30 years, in two field trials: one established in their natural range (Brețcu trial), while the second was located outside of their natural range, in Subcarpathian lands (Avrig trial). Significant $(\mathrm{p}<0.05)$ differences were found among the seed stands in both sites for most of the characteristics, suggesting an additive genetic control with different levels of significance depending on the evaluated trait and the testing site. Location analysis also revealed a highly significant population $\mathrm{x}$ locality interaction for all traits. The same populations behave differently to the change of the ecological conditions. In the Avrig trial higher values were recorded than in the Brețcu trial for the tree slenderness coefficient (19\%), crown slenderness coefficient (13.6\%) and crown lateral area (9.4\%). Although outside of their natural area, pruning height $(\mathrm{m})$ increased $6.4 \%$, however pruning height ratio (\%) decreases by $1 \%$, compared to the test established in their natural range. The populations from the Eastern Carpathians stand out by showing sustained growth and superior wood quality, while the populations from the Western Romanian Carpathians have generally smaller differences between the mean values of analysed traits in both field trials. Qualitative characteristics that influence the stability of stands to windthrow and snowbreak showed low levels of correlations to ecological gradients of the originating location of tested seed stands.
\end{abstract}

Keywords: Carpathian forests, field trials, phenotypic and ecological correlations, Picea abies, tested seed sources

\section{Introduction}

One of the most important tree species from Europe, the Norway spruce [Picea abies (L.) Karst.], covers approximately $23.4 \%$ of the entire Romanian forest area and $77 \%$ of coniferous forests. In the Romanian Carpathians, Norway spruce is the predominant species at altitudes between 1200 and $1800 \mathrm{~m}$ (Feurdean et al., 2011). It is found in pure spruces stands, located at high and medium altitudes ranges, and in mixed stands with Silver fir and European beech, which are localised mainly in low and medium mountain zones (Şofletea and Curtu, 2007).

This study analyses qualitative stem and crown characteristics in order to test the genetic value of open-pollinated progeny at 33 Norway spruce seed sources, in two field trials (Avrig and Brețcu) installed in 1980. The stem and crown characteristics are very important for trees stability against the wind and snow, for the wood quality, and also to predict the biomass assimilation. For this reasons, the stem and crown traits were previous analysed in many studies (Kantola and Mäkelä, 2006; Kilpelainen et al., 2010; Mäkinen and Hein, 2006; Mihai, 2009).

The data obtained will be used to identify populations in the Carpathian areas where the Norway spruce has a better capacity for adaptation to environmental condi- tions, to enable sustainable forest management, and especially to ensure their increased stability. The behaviour of populations originated from different Carpathian branches, the results of local or nearest to testing site populations and of the population 5-Moldovița (I.U.F.R.O. standard provenance), as well as the correlations between analysed traits, and between these and the ecological gradients of the seed stands origin, are a further working hypothesis in this study. Also, the data obtained will be complementary to those obtained in Norway spruce field trials performed in various countries (e.g. France, Poland, Bulgaria, Finland, Hungary and Romania), where many populations originating from the Romanian Carpathians are considered superior to local populations and to the populations of other geographical areas (Alexandrov and Stancova, 1997; Enescu and Ioniță, 2002; Giertych, 1993; Héois and Van de Sype, 1991; Naapola, 1997; Tollefsrud et al., 2008; Ujvari and Ujvari, 2006), including in terms of their high capacity for biomass assimilation.

\section{Materials and methods}

Plant material

Selection of the 33 seed stands included in the experiment (Tab. 1) was based on representativeness criterion, 
594

Tab. 1. Location of the tested seed stands (Şofletea 2012)

\begin{tabular}{|c|c|c|c|c|c|}
\hline Code & $\begin{array}{l}\text { Seed sources } \\
\left.\text { (Carpathian branch }^{*}\right)\end{array}$ & $\begin{array}{l}\text { Altitude }[\mathrm{m}] / \\
\text { latitude }[\mathrm{N}] / \\
\text { longitude }[\mathrm{E}] /\end{array}$ & Code & $\begin{array}{l}\text { Seed sources } \\
\text { (Carpathian branch*) }^{*}\end{array}$ & $\begin{array}{l}\text { Altitude }[\mathrm{m}] / \\
\text { latitude }[\mathrm{N}] / \\
\text { longitude }[\mathrm{E}] /\end{array}$ \\
\hline 1 & Coşna (EC) & $1025 / 47^{\circ} 28^{\prime} / 25^{\circ} 10^{\prime}$ & 18 & Braşov (CC) & $1020 / 45^{\circ} 35^{\prime} / 25^{\circ} 35^{\prime}$ \\
\hline 2 & Dorna Candreni (EC) & $990 / 47^{\circ} 17^{\prime} / 25^{\circ} 05^{\prime}$ & 19 & Azuga (CC) & $1210 / 45^{\circ} 28^{\prime} / 25^{\circ} 40^{\prime}$ \\
\hline 3 & Frasin $(\mathrm{EC})$ & $755 / 47^{\circ} 28^{\prime} / 25^{\circ} 48^{\prime}$ & 20 & Domneşti (SC) & $650 / 45^{\circ} 11^{\prime} / 24^{\circ} 49^{\prime}$ \\
\hline 4 & Marginea (EC) & $670 / 47^{\circ} 49^{\prime} / 25^{\circ} 50^{\prime}$ & 21 & Orăştie (SC) & $680 / 45^{\circ} 43^{\prime} / 23^{\circ} 16^{\prime}$ \\
\hline 5 & Moldovița (EC) & $855 / 47^{\circ} 39^{\prime} / 25^{\circ} 34^{\prime}$ & 22 & Bistra (SC) & $1350 / 45^{\circ} 35^{\prime} / 23^{\circ} 45^{\prime}$ \\
\hline 6 & Stulpicani (EC) & $985 / 47^{\circ} 22^{\prime} / 25^{\circ} 46^{\prime}$ & 23 & Voineasa (SC) & $1410 / 45^{\circ} 17^{\prime} / 23^{\circ} 55^{\prime}$ \\
\hline 7 & Năsăud (EC) & $1210 / 47^{\circ} 28^{\prime} / 24^{\circ} 25^{\prime}$ & 24 & Retezat (SC) & $970 / 45^{\circ} 27^{\prime} / 22^{\circ} 51^{\prime}$ \\
\hline 8 & Prundul Bârgăului(EC) & $1290 / 47^{\circ} 05^{\prime} / 24^{\circ} 45^{\prime}$ & 25 & Bozovici (BM) & $600 / 44^{\circ} 57^{\prime} / 21^{\circ} 59^{\prime}$ \\
\hline 9 & Rodna (EC) & $890 / 47^{\circ} 26^{\prime} / 24^{\circ} 50^{\prime}$ & 26 & Vãliug (BM) & $940 / 45^{\circ} 12^{\prime} / 22^{\circ} 02^{\prime}$ \\
\hline 10 & Sânmartin (EC) & $900 / 46^{\circ} 13^{\prime} / 25^{\circ} 57^{\prime}$ & 27 & Beliş (AM) & $1210 / 46^{\circ} 32^{\prime} / 23^{\circ} 02^{\prime}$ \\
\hline 11 & Toplița (EC) & $910 / 46^{\circ} 45^{\prime} / 25^{\circ} 20^{\prime}$ & 28 & Turda (AM) & $1200 / 46^{\circ} 33^{\prime} / 23^{\circ} 02^{\prime}$ \\
\hline 12 & Gurghiu (EC) & $1225 / 46^{\circ} 45^{\prime} / 24^{\circ} 50^{\prime}$ & 29 & Beiuș (AM) & $520 / 46^{\circ} 52^{\prime} / 22^{\circ} 23^{\prime}$ \\
\hline 13 & Sovata (EC) & $1190 / 46^{\circ} 40^{\prime} / 25^{\circ} 05^{\prime}$ & 30 & Dobreşti (AM) & $510 / 46^{\circ} 53^{\prime} / 22^{\circ} 20^{\prime}$ \\
\hline 14 & Tarcău (EC) & $930 / 46^{\circ} 54^{\prime} / 26^{\circ} 06^{\prime}$ & 31 & Sudrigiu (AM) & $1050 / 46^{\circ} 31^{\prime} / 22^{\circ} 35^{\prime}$ \\
\hline 15 & Comandău (CC) & $1150 / 45^{\circ} 45^{\prime} / 26^{\circ} 20^{\prime}$ & 32 & Câmpeni (AM) & $1237 / 46^{\circ} 25^{\prime} / 23^{\circ} 10^{\prime}$ \\
\hline 16 & Nehoiu (CC) & $1120 / 45^{\circ} 37^{\prime} / 26^{\circ} 30^{\prime}$ & 33 & Gârda (AM) & $1295 / 46^{\circ} 29^{\prime} / 22^{\circ} 55^{\prime}$ \\
\hline 17 & Nehoiașu (CC) & $1080 / 45^{\circ} 30^{\prime} / 26^{\circ} 10^{\prime}$ & & & \\
\hline
\end{tabular}

EC - Eastern Carpathians; CC - Curvature Carpathians; SC - Southern Carpathians; BM - Banat Mountains; AM - Apuseni Mountains; BM+AM = Western Romanian Carpathians.

with the goal of having at least one valuable population from each $\mathrm{R}$ of $\mathrm{p}$. Tested trees came from seedlings resulting from 10 open-pollinated seed trees for each population (Enescu and Ioniță, 2002).

The two field trials were established in different environmental conditions. The Avrig trial was located outside the Norway spruce's natural distribution range, in the Southern Subcarpathians, at $615 \mathrm{~m}$ altitude (about $300 \mathrm{~m}$ lower than the natural limit), at $45^{\circ} 39^{\prime} 36^{\prime \prime} \mathrm{N}$ and $24^{\circ} 26^{\prime} 12^{\prime \prime}$ E (Budeanu et al., 2012). The average annual temperature is $8.3^{\circ} \mathrm{C}$ and the mean annual precipitation is $680 \mathrm{~mm}$ (ANM, 2011). The Brețcu trial was located in the ecological optimum for the species, in the transition zone between the Eastern Carpathians and the Curvature Carpathians, at $1100 \mathrm{~m}$ average altitude, at $45^{\circ} 58^{\prime} 16^{\prime \prime} \mathrm{N}$ and $26^{\circ} 24^{\prime} 12^{\prime \prime}$ E (Budeanu et al., 2012). The average annual temperature is $4.8^{\circ} \mathrm{C}$ and the mean annual precipitation is $830 \mathrm{~mm}$ (ANM, 2011).

\section{Experimental design and sampling}

In both trials the experimental design was an incomplete balanced square grid design, type $6 \times 6$, with three replications and 49 seedlings per plot planted at 2 by 2 $\mathrm{m}$ spacing (Budeanu et al., 2012). Three of the 33 tested populations (The 1-3 code numbers) are repeated in each replication for completing the experimentally plot.

\section{Data analysing}

According to the methodology of data collection in such field trials developed by IUFRO (Lines, 1967), in each unitary plot evaluations were performed on 10 trees, so that for each local population 30 trees were measured, and the total number of trees studied in each trial was 1080.

The following measurements and determinations were taken concerning the following characteristics (traits):

A) Measured variables:

- Total height $(\mathrm{TH})$ and diameter at breast height (DBH);

- Pruning height $(\mathrm{PH})$, the height from the ground to first green branch;

- Crown diameter (CD), as an average between the maximum and minimum value measured at the base of the crown.

B) Calculated parameters:

- Pruning height ratio $(\mathrm{PHR})=(\mathrm{PH} / \mathrm{TH}) \times 100$;

- Tree slenderness coefficient $($ TSC $)=\mathrm{TH} / \mathrm{DBH}$;

- Crown slenderness coefficient $(\mathrm{CSC})=\mathrm{TH} / \mathrm{CD}$;

- Crown ratio $(\mathrm{CR})=(\mathrm{TH}-\mathrm{PH}) / \mathrm{TH} \times 100$;

- Crown lateral area $(\mathrm{CLA})=(\mathrm{CH} \times \mathrm{CD}) / 2$, where $\mathrm{CH}$ is the height of the crown.

Applying ANOVA, variance components due to influence of populations and replications were determined, as well as residual variance. Corresponding to the experimental design used, the mathematical model for the analysis of variances was that recommended by Nanson (2004) and White et al. (2007):

$$
X_{i j k}=m+\alpha_{i}+\beta_{j}+\varepsilon_{i j}
$$


where: $\mathrm{m}=$ overall average value, $\alpha_{i}=$ component of $\mathrm{i}$ populations $(i=1 \ldots a), \beta_{j}=$ component of $j$ replications in $i$ populations $(\mathrm{j}=1 \ldots \mathrm{b}), \varepsilon_{i j}=$ random error affecting ij plots.

To determined what part of the variation was caused by populations and environment the bi factorial analyzed model were also used (Nanson, 2004):where: $\mathrm{m}$ and $\alpha \mathrm{i}$

$$
X_{i j k}=m+\alpha_{i}+\beta_{j}+\alpha \beta_{i j}+\varepsilon_{i j k}
$$

have the same signification, $\beta_{j}=$ component of $j$ localities $(\mathrm{j}=1 \ldots \mathrm{b}), \alpha \beta_{i j}=$ interaction of $\mathrm{i}$ populations with $\mathrm{j}$ localities, $\varepsilon_{i j} \mathrm{k}=$ random error.

The level of significance was established using the Fisher's $(\mathrm{F})$ test and the population ranking and their homogeneous groups were determined using the Duncan's test ( $\mathrm{p}$ $=5 \%$ ). Also determined was the simple Pearson correlations between traits, and between traits and the ecological gradients of the originating seed stands. The most important multiple correlations were also determined.

All statistical analysis and graphs were performed using Statistica 8.0 and Excel.

\section{Results and discussions}

\section{Pruning height (PH) and (PHR)}

Pruning height mean value was $9.3 \mathrm{~m}$ in Avrig trial $(\mathrm{PHR}=50 \%)$ and $8.7 \mathrm{~m}$ in Brețcu trial $(\mathrm{PHR}=51 \%)$. For $78.8 \%$ of the tested seed stands the PHR values were higher for the field trial located in the Norway spruce's natural distribution range.

The comparative analyse of PHR values of both testing sites showed certain differences due to the populations being from different Carpathian branches. Thus, the greatest difference between the two testing sites was for the seed stands originating in the Western Romanian Carpathians, and was $4.5 \%$. The populations from the Eastern Carpathians were the most stable with reference to the PHR values, the average difference between the two tested sites being $1.6 \%$. In fact, from the total populations identified as valuable for this trait, more than half belonged to the Eastern Carpathians. Even when higher PH values were seen ONR, no matter which Carpathian branch they originated from, the average value for the Eastern Carpathians was higher than the average for the rest of the Carpathian branches by $5.7 \%$ to $6.8 \%$ (Fig. 1).

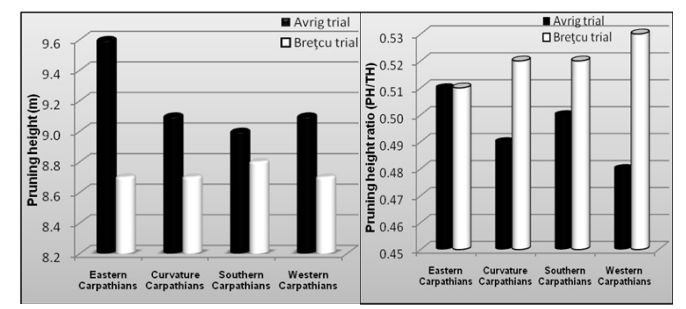

Fig. 1. Pruning height and pruning height ratio in different branches of Romanian Carpathians
This situation was generated through the more active height growths ONR of the seed stands from the Eastern Carpathians, also revealed in other field trials located in the Carpathians or in other geographic areas (Budeanu et al., 2012; Héois and Van de Sype, 1991; Mihai, 2009). For both experiments ANOVA (Tab. 2) revealed highly significant differences $(\mathrm{p}<0.001)$ between the seed stands. Factorial Anova (Tab. 3) shows a very significant influence of the test site, but in the same time highly significant differences among populations also resulted.

In both trials, local provenances were ranked in the second half, concerning PHR. The I.U.F.R.O. standard provenance (5-Moldovița) was registered a PHR of 50\% (rank 16) ONR and 53\% (rank 11) in the Brețcu test.

The PH was higher by $6.4 \%$ in the Avrig test, located ONR, as a result of higher values for total height $(\mathrm{TH})$. In fact, between $\mathrm{TH}$ and $\mathrm{PH}$ there is a highly significant and positive correlation (Tab. 4), of greater intensity in Avrig trial $(r=0.30)$, compared to Brețcu trial. At the same time, the influence of the latitude of the seed stands origin was seen only in Avrig test $(\mathrm{r}=0.11)$.

The PH values of approximately $50 \%$ of the total height have been reported in other studies in Romania, both in provenance trials, at the age of 40 years (Mihai, 2009) and in natural cvasivirgine stands (Florescu et al., 2002). The correlation between $\mathrm{PH}$ and $\mathrm{TH}$ determined by Mihai (2002) in a series of provenance trials analysed at the age of 25 years was higher than in our study, varying between 0.59 and 0.93 .

In Sweden, the PHR was only $22 \%$ of the total height, at the average age of 66 years of the trees analysed (Petersson, 1997). Relatively small values of PH were recorded for Sweden in trials on 30 year-old spruce (Norén and Persson, 1997). However, in northern European spruce stands a highly significant correlation between $\mathrm{PH}$ and the TH was seen, as recorded by Tahvanainen and Forss (2008) in a study in Finland.

\section{Tree slenderness coefficient (TSC)}

In the field trial established ONR, as a consequence of the much more active height growths favoured by the specific site conditions, all the tested seed stands registered higher values for the TSC. The TSC average value was 101.6 in the Avrig test and 85.4 in the Brețcu test (19\% difference). The amplitude of variation was about 2.4 times higher in the test placed outside of the natural area.

In accordance with this, applying the ANOVA test showed distinctly significant values between the seed stands in the Avrig test $(\mathrm{p}<0.01)$, but no significant differences in the Brețcu test (Tab. 2). Two way Anova (Tab. 3) shows a very significant influence of the test site, but in the same time a highly significant populations $\mathrm{x}$ locality interaction, suggesting that the same population react different to the changing of the environmental conditions. That conclusion is valuable for all of the analyzed traits. 
596

Tab. 2. ANOVA for the pruning height (PH), tree slenderness coefficient (TSC), crown slenderness coefficient (CSC), crown ratio (CR) and crown lateral area (CLA)

\begin{tabular}{|c|c|c|c|c|c|c|c|c|}
\hline Trait & $\begin{array}{l}\text { Source of } \\
\text { Variance }\end{array}$ & $\mathrm{DF}$ & $\begin{array}{c}\text { Sum of Squares } \\
\text { Avrig trial }\end{array}$ & $\begin{array}{c}\text { Mean } \\
\text { Square }\left(\mathrm{s}^{2}\right)\end{array}$ & $\mathrm{F}_{\text {value }}$ & Sum of Squares & $\begin{array}{c}\text { Mean Square }\left(\mathrm{s}^{2}\right) \\
\text { Brețcu trial }\end{array}$ & $\mathrm{F}_{\text {value }}$ \\
\hline \multirow{3}{*}{$\mathrm{PH}$} & Replication & 2 & 16.85 & 8.42 & - & 65.95 & 32.98 & - \\
\hline & Population & 35 & 372.88 & 10.65 & $6.51^{* * *}$ & 169.76 & 4.85 & $3.13^{* * *}$ \\
\hline & Error & 1042 & 1704.92 & 1.64 & - & 1617.25 & 1.55 & - \\
\hline \multirow{3}{*}{ TSC } & Replication & 2 & 1441 & 721 & - & 590 & 295 & - \\
\hline & Population & 35 & 17986 & 514 & $1.91^{* *}$ & 10423 & 298 & 1.39 \\
\hline & Error & 1042 & 280295 & 269 & - & 223745 & 215 & - \\
\hline \multirow{3}{*}{$\mathrm{CSC}$} & Replication & 2 & 37.16 & 18.58 & - & 219.09 & 109.54 & - \\
\hline & Population & 35 & 355.1 & 10.15 & $2.03^{* * *}$ & 230.87 & 6.60 & $1.60^{*}$ \\
\hline & Error & 1042 & 5210.73 & 5.00 & - & 4304.82 & 4.13 & - \\
\hline \multirow{3}{*}{ CR } & Replication & 2 & 0.0271 & 0.0135 & - & 0.2159 & 0.108 & - \\
\hline & Population & 35 & 0.6748 & 0.0193 & $3.32^{* * *}$ & 0.5611 & 0.016 & $2.35^{* * *}$ \\
\hline & Error & 1042 & 6.0575 & 0.0058 & - & 7.1204 & 0.0068 & - \\
\hline \multirow{3}{*}{ CLA } & Replication & 2 & 416.8 & 208.4 & - & 881.4 & 440.7 & - \\
\hline & Population & 35 & 5240.3 & 149.7 & $2.58^{* * *}$ & 1884.5 & 53.8 & $1.47^{*}$ \\
\hline & Error & 1042 & 60401.5 & 58.0 & - & 38163.8 & 36.6 & - \\
\hline
\end{tabular}

$\mathrm{DF}=$ Degrees of freedom; ${ }^{*} \mathrm{p}<0.05 ;{ }^{* *} \mathrm{p}<0.01 ;{ }^{* * *} \mathrm{p}<0.001$.

Tab. 3. Factorial ANOVA for the Norway spruce populations combined over locations

\begin{tabular}{|c|c|c|c|c|c|c|c|}
\hline $\begin{array}{l}\text { Source of } \\
\text { variation }\end{array}$ & D.F. & Trait & $\begin{array}{l}\text { Sum of } \\
\text { squares }\end{array}$ & $\begin{array}{c}\text { Mean } \\
\text { squares }\left(s^{2}\right)\end{array}$ & Trait & Sum of squares & Mean squares $\left(s^{2}\right)$ \\
\hline Locality & 1 & \multirow{4}{*}{$\begin{array}{l}\text { Pruning } \\
\text { height }\end{array}$} & 189.5 & $190^{* * *}$ & \multirow{4}{*}{$\begin{array}{c}\text { Tree } \\
\text { slenderness } \\
\text { coefficient }\end{array}$} & 140683 & $140683^{* * *}$ \\
\hline Population & 35 & & 302.6 & $8.6^{* * *}$ & & 10410 & 297 \\
\hline $\begin{array}{c}\text { Population } \\
\text { x locality }\end{array}$ & 35 & & 240.0 & $6.9^{* * *}$ & & 17998 & $514^{* * *}$ \\
\hline Error & 2088 & & 3405.0 & 1.6 & & 506071 & 242 \\
\hline Locality & 1 & \multirow{4}{*}{$\begin{array}{c}\text { Crown } \\
\text { slenderness } \\
\text { coefficient }\end{array}$} & 498.91 & $499^{* * *}$ & \multirow{4}{*}{$\begin{array}{c}\text { Crown } \\
\text { lateral area }\end{array}$} & 1163.4 & $1163^{* * *}$ \\
\hline Population & 35 & & 224.24 & 6.4 & & 3163.5 & $90.4^{* *}$ \\
\hline $\begin{array}{l}\text { Population } \\
\text { x locality }\end{array}$ & 35 & & 361.73 & $10.3^{* * *}$ & & 3957.6 & $113.1^{* * *}$ \\
\hline Error & 2088 & & 9771.80 & 4.68 & & 99873.6 & 47.8 \\
\hline
\end{tabular}

$\mathrm{DF}=$ Degrees of freedom $;{ }^{*} \mathrm{p}<0.05 ;{ }^{* *} \mathrm{p}<0.01 ;{ }^{* * *} \mathrm{p}<0.001$.

The largest differences between the two testing sites were seen for the populations coming from the Southern Carpathians (22.5\%) and Eastern Carpathians (21.5\%). These showed on the average the lowest values for the test located INR, and the highest ones for the test located ONR. In the test from outside the Norway spruce's natural distribution range we noted the Western Romanian Carpathians seed stands, because approximately $44 \%$ of them had values for TSC below 100 in Avrig test.

The seed stands situated at the smallest distance from the two testing sites (as local populations) showed different reactions. Thus, the local population 22-Bistra showed in the Avrig test one of the highest values for the TSC (107), which was a difference of $27.4 \%$ to the test in the natural area. In the Brețcu trial, the two local populations (10-Sânmartin and 15-Comandău) registered close values to the average for the entire trial ( 84 and 85 , respectively).
The values for TSC determined in our study are very close to those reported by Mihai (2009) for two provenance trials in Romania, on tress of 40 years of age, one situated outside the natural distribution range and one situated in the ecological optimum for the Norway spruce, in which higher values were also seen for trees outside of their natural range. The TSC decreases with age, and in mature stands in the Romanian Carpathians does not exceed a value of 80 (Florescu et al., 2002). In Germany, at the same age (100 years), TSC increased according to stand productivity and increasing number of trees per hectare: 51 for 350 trees / ha and 84 for 1600 trees / ha (Mäkinen and Hein, 2006; Schmidt and Kändler, 2009). In Finland, at the age of 52 and 60 years a TSC of 89 and 85 , respectively was observed (Rautiainen et al., 2008; Repola, 2009). In Norway, at the age of 30 years, of five examined full-sib field trials, the TSC had a value of 89 (Steffenrem et al., 
Tab. 4. Correlation coefficients matrix

\begin{tabular}{|c|c|c|c|c|c|c|}
\hline Variables & $\mathrm{PH}$ & TSC & CSC & $\mathrm{CD}$ & $\mathrm{CR}$ & CLA \\
\hline \multicolumn{7}{|c|}{ AVRIG field trial } \\
\hline Pruning height & - & 0.02 & $0.15^{* * *}$ & -0.05 & $-0.73^{* * *}$ & $-0.20^{* * *}$ \\
\hline Tree slenderness coefficient & & - & $0.73^{* * *}$ & $-0.81^{* * *}$ & $-0.49^{* * *}$ & $-0.77^{* * *}$ \\
\hline $\begin{array}{c}\text { Crown slenderness } \\
\text { coefficient }\end{array}$ & & & - & $-0.87^{* * *}$ & $-0.53^{* * *}$ & $-0.75^{* * *}$ \\
\hline Crown diameter & & & & - & $0.57^{* * *}$ & $0.95^{* * *}$ \\
\hline Crown ratio & & & & & - & $0.73^{* * *}$ \\
\hline Crown lateral area & & & & & & - \\
\hline Total height & $0.30^{* * *}$ & $-0.66^{* * *}$ & $-0.52^{* * *}$ & $0.74^{* * *}$ & $0.43^{* * *}$ & $0.79^{* * *}$ \\
\hline Radial increment & 0.01 & $-0.62^{* * *}$ & $-0.34^{* * *}$ & $0.52^{* * *}$ & $0.21^{* * *}$ & $0.55^{* * *}$ \\
\hline Survival rate & $0.09^{*}$ & $0.19^{* * *}$ & $0.14^{* * *}$ & $-0.16^{* * *}$ & $-0.20^{* * *}$ & $-0.20^{* * *}$ \\
\hline Latitude $(\mathrm{N})$ & $0.11^{* *}$ & 0.00 & -0.05 & $0.06^{*}$ & -0.03 & $0.06^{*}$ \\
\hline Corrected Latitude & 0.00 & -0.03 & 0.02 & 0.02 & 0.00 & 0.02 \\
\hline Longitude (E) & $0.09^{*}$ & 0.03 & 0.03 & -0.05 & $-0.08^{*}$ & $-0.07^{*}$ \\
\hline Altitude & -0.05 & -0.03 & 0.00 & -0.01 & 0.01 & -0.01 \\
\hline \multicolumn{7}{|c|}{ BREȚCU field trial } \\
\hline Pruning height & - & 0.05 & $0.10^{* *}$ & $-0.06^{*}$ & $-0.78^{* * *}$ & $-0.33^{* * *}$ \\
\hline Tree slenderness coefficient & & - & $0.69^{* * *}$ & $-0.78^{* * *}$ & $-0.49^{* * *}$ & $-0.77^{* * *}$ \\
\hline $\begin{array}{c}\text { Crown slenderness } \\
\text { coefficient }\end{array}$ & & & - & $-0.89^{* * *}$ & $-0.42^{* * *}$ & $-0.73^{* * *}$ \\
\hline Crown diameter & & & & - & $0.48^{* * *}$ & $0.90^{* * *}$ \\
\hline Crown ratio & & & & & - & $0.75^{* * *}$ \\
\hline Crown lateral area & & & & & & - \\
\hline Total height & $0.20^{* * *}$ & $-0.70^{* * *}$ & $-0.49^{* * *}$ & $0.67^{* * *}$ & $0.45^{* * *}$ & $0.74^{* * *}$ \\
\hline Radial increment & $-0.13^{* * *}$ & $-0.58^{* * *}$ & $-0.09^{*}$ & $0.22^{* * *}$ & $0.28^{* * *}$ & $0.40^{* * *}$ \\
\hline Survival rate & $0.13^{* * *}$ & $0.09^{*}$ & $0.18^{* * *}$ & $-0.21^{* * *}$ & $-0.15^{* * *}$ & $-0.20^{* * *}$ \\
\hline Latitude (N) & 0.00 & -0.01 & 0.02 & -0.02 & 0.03 & 0.00 \\
\hline Corrected Latitude & $0.06^{*}$ & -0.02 & 0.04 & -0.01 & -0.04 & -0.01 \\
\hline Longitude (E) & -0.02 & -0.04 & $-0.06^{*}$ & 0.05 & 0.02 & 0.02 \\
\hline Altitude & $0.07^{*}$ & -0.02 & 0.03 & 0.00 & -0.05 & -0.01 \\
\hline
\end{tabular}

All correlations were established for 1080 trees / trial, excepted the correlations with radial increment, calculated for 324 trees / trial

2007), while in France, at the same age, it was 86 (Colin and Houllier, 1992). The measurements made in a field trial established in Poland (Rozkowski, 2004) identified intense and highly significant correlations between pruning height at 36 years old and total height reached at the age of $9(\mathrm{r}=0.68)$, with a base surface at age $13(\mathrm{r}=0.65)$.

Conversely, our evaluations made in the two field trials showed that the TSC did not correlated with the gradients of the geographic location of populations' origin (Tab. 4). In both trials negative and significant correlations were seen with the mean radial increment $(r=-0.62$ in the Avrig trial and $r=-0.58$ in the Brețcu trial).

The reduction of TSC with age is a beneficial adaptive response for spruce. Higher values recorded, especially in trials from outside the natural range in pre-mountainous areas, as in the Avrig trial, determine vulnerabilities. In fact, values for TSC higher than 80 are considered critical for spruce (Abetz, 1987).

\section{Crown characteristics}

Because of the $10.6 \%$ lower average values for the total height in the Brețcu trial, but $9.6 \%$ higher for the crown diameter, the Crown slenderness coefficient (CSC) is $17.5 \%$ higher in the test located outside the natural range. In the

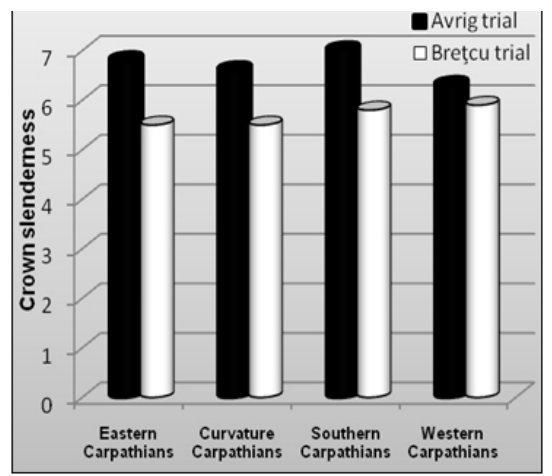

Fig. 2. Crown slenderness coefficient in different branches of the Carpathians

Carpathian branches the CSC values are 20.0\% - 23.6\% higher in the Avrig trial for the seed stands originating in the Eastern Carpathians, the Curvature Carpathians and 
598

the Southern Carpathians, but only 6.8\% higher in the Western Carpathians (Fig. 2).

Trees with large height generated low levels for CSC in both testing sites. However, the negative correlation between the mean annual radial increment and CSC was more intense and significant ONR (Tab. 4). Of the total biomass production, the twigs and the needles contribute $40 \%$ (Kilpelainen et al., 2010). However, well-developed crowns are an opportunity for abundant fructification (White et al., 2007).

Due to the fact that at older ages the CSC reduces, it is expected that the proportion of biomass stored in the trunk will grow.

Crown ratio $(\mathrm{CR})$ is another very important trait for measuring the accumulation of biomass in spruce. In fact, Kantola and Mäkelä (2006) considered this parameter as a key source of structural variation between different ages and social positions. The value determined by the aforementioned authors, at the age of 30 - 40 years was $18 \%$ higher than that recorded in this paper (50\%). Colin and Houllier (1992) indicate a roughly exponential function for CR decreasing with age, and in Norway spruce stands in Finland there is a negative correlation between CR and TSC, with the value $r=-0.38$. In our study, in both trials this correlation was highly significant $(r=-0.49)$.

The crown lateral area (CLA) was approximately 15 $\mathrm{m} 2$ and showed an increasing trend in the trial located ONR (+9.7\%). The seed stands originating in the Southern Carpathians represented an exception, the balance between the CLA values in the two trials being almost zero. The greatest differences between the two trials were seen

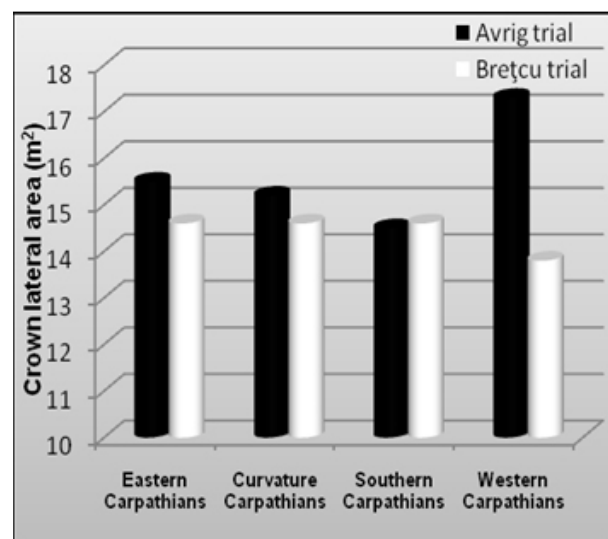

Fig. 3. Average values of crown lateral area according to the seed stands origin

between the seed stands originating in the Western Romanian Carpathians, for which the values were $25.4 \%$ higher in the Avrig test (Fig. 3). We also noted that the CLA was increased ONR, but the behaviour in the two trials differed between different branches of the Carpathians.

The CLA was highly and positively correlated with the mean annual RI, but correlated more strongly in the ONR trial (Tab. 4). The correlation was much stronger in relation to the total height $(r=0.79 ; r=0.74)$. The positive effect of CLA determined on the radial increment and height was highlighted by the multiple correlation presented in Fig. 4.

In order to increase the stability of Norway spruce stands, in conjunction with their native potential concerning stem and crown traits, other complementary silviculturale procedures (such as establishment of mixed stands, formation of well balanced stems and crowns by early thinning of the stands, proper distribution of the

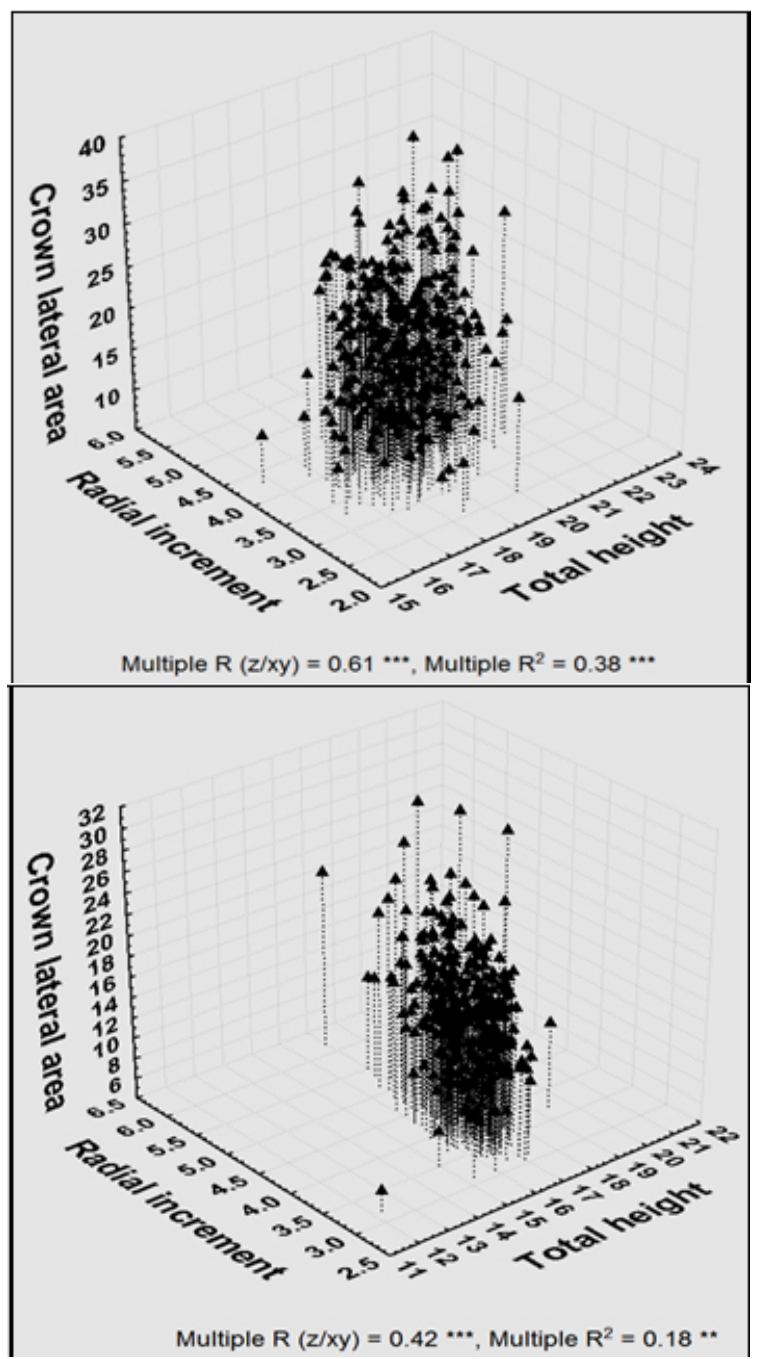

Fig. 4. Multiple correlation between CLA, RI and TH in Avrig (left) and Brețcu (right) trials

stand in the timber harvesting process, etc.) must be taken into account, as they proved to be very efficient even in conditions of strong impact from harmful environmental factors (Klopcic et al., 2009; Schütz et al., 2006).

\section{Conclusions}

The Norway spruce populations adapted to the mountainous environmental conditions, showed, in the field trial located outside of their natural distribution range, 
an evident accentuation of the stem and crown traits that generate vulnerability against the disruptive effects of wind and snow. These results confirm the risks of planting the Norway spruce outside its natural distribution range.

The fact that the populations react different to the changing of the environmental conditions, revealed by Anova, indicate an increased risk of forest reproductive material transfer without a scientific base provided by the multisite field trials.

The correlations between the traits involved in the temporal and spatial stability of stands, as well as the correlations determined by the geographic gradients, confirm the utility and necessity of evaluations using multisite trials in the management of risks for Norway spruce stands.

Having a high bioaccumulation potential in the lands situated outside the natural range and also having smaller slenderness indices, Western Romanian Carpathian seed stands could be used as a source for supplying seeds to installed the biomass cultures in the areas protected from the harmful action of the abiotic factors (wind and snow).

\section{Acknowledgement}

We wish to thank to Dr. Lucia Ioniță for the acces to the field trials documentation and to our devoted colleagues: Dan Pepelea, Cătălin Cojanu, Mirabela Marin and Gruiță Ienăşoiu for their help in the field measurements. This paper is financed by the National Forest Administration (Romsilva) in the frame of Romsilva Research Programme contracted with Forest Research and Management Institute (Project 11.30). We would like to thank to Dr. Jan Kowalczyk for the important contribution in improving the manuscript.

\section{References}

Abetz P (1987). Why the crop tree aligned thinning system increases the stability and productivity of stands. In: Development of thinning systems to reduce stand damages. Knutell H. (ed.): Proceedings of IUFRO Group S1.05-05, Garpenberg, pp. 35-42.

Alexandrov A, Stankova T (1997). Norway spruce provenance trials in Bulgaria. IUFRO Norway spruce symposium, Stara Lesna, Slovakia.

Budeanu M, Şofletea N, Pârnuță G (2012). Testing Romanian seed sources of Norway spruce (Picea abies): Results on growth traits and survival at age 30. Ann For Res 55(1):4352.

Colin F, Houllier F (1992). Branchiness of Norway spruce in northeastern France: predicting the main crown characteristics from usual tree measurements. Ann For Sci 49:511538.

Enescu V, Ioniță L (2002). Inter and intra populations genetic variation of some Norway spruce (Picea abies (L.) Karst) forest genetic resources. Ann Forest Res 45:67-77 (in Romanian).

Feurdean A, Tanțău I, Fărcaş S (2011). Holocene variability in the range distribution and abundance of Pinus, Picea abies, and Quercus in Romania; implications for their current status. Quaternary Science Reviews 30:3060-3075.

Florescu I, Chițea G, Spârchez G, Dieter S, Petrițan I, Filipescu C (2002). Particularities concerning the structuring and functioning of quasivirgine forest ecosystems in the Braşov mountains. Ann For Res 45:21-30 (in Romanian).

Giertych M (1993). Breeding Norway spruce in Poland: from provenance tests to seed orchards, Norway spruce provenances and breeding. Proceedings of IUFRO (S2.2-11) Symposium, Latvia, pp. 193-199.

Héois B, Van de Sype H (1991). Genetic variability of fifteen Romanian provenances of Norway spruce (Picea abies (L) Karst.). First results. Ann For Sci 48:179-192 (in French).

Kantola A, Mäkelä A (2006). Development of biomass proportions in Norway spruce (Picea abies [L.] Karst.). Trees 20:111-121.

Kilpelainen A, Routa J, Peltola H, Zubizarreta Gerendiain A, Pulkkinen P, Kellomaki S (2010). Effects of genetic entry and competition on above ground biomass production of Norway spruce grown in southern Finland. For Ecol Manage 259:2327-2332.

Klopcic M, Poljanec A, Gartner A, Boncina A (2009). Factors related to natural disturbances in mountain Norway spruce (Picea abies) forests in the Julian Alps. Ecoscience 16:48-57.

Lines R (1967). Standardization of methods for provenances research and testing. XIV IUFRO Congress III, pp. 672-719.

Mäkinen H, Hein S (2006). Effect of wide spacing on increment and branch properties of young Norway spruce. Eur J Forest Res 125:239-248.

Mihai G (2002). Researches of Norway spruce multisite provenances comparative trials. $\mathrm{PhD}$ Thesis, Ed. Transilvania University, Braşov (in Romanian).

Mihai G (2009). Tested seed sources for the main forest tree species from Romania. Romanian Forestry Publishing House, Bucureşti (in Romanian).

Naapola ML (1997). The growth and adaptation of the IUFRO 1964/1968 Norway spruce provenance material in Finland. IUFRO Norway spruce Symposium, Stara Lesna, Slovakia

Nanson A (2004). Genetic and forest trees breeding. Ed. Gembloux, Belgium (in French).

Norén A, Persson A (1997). Graded quality of 30-year-old Norway spruce grown on agricultural and forest land. Studia Forestalia Suecica, Swedish University of Agricultural Sciences, Faculty of Forestry, No: 203, Uppsala, Sweden.

Pârnuță G, Lorenț A, Tudoroiu M, Petrilă M (2010). Regions of provenances of basic materials for forest reproductive materials in Romania. Romanian Forestry Publishing House, Bucureşti (in Romanian).

Petersson H (1997). Functions for predicting crown height of Pinus sylvestris and Picea abies in Sweden. Scand J For Res 12(2):179-188.

Rautiainen M, Mottus M, Stenberg P, Ervasti S (2008). Crown 
600 envelope shape measurements and models. Silva Fennica 42(1):19-33.

Repola J (2009). Biomass equations for Scots pine and Norway spruce in Finland. Silva Fennica 43(4):625-647.

Rozkowski R (2004). Breeding value of Norway spruce (Picea abies (L.) Karst.) from the Klodzko forest district (SW Poland). J For Sci 50(1):17-23.

Schmidt M, Kändler G (2009). An analysis of Norway spruce stem quality in Baden-Württemberg: results from the second German national forest inventory. Eur J Forest Res 128:515-529.

Schütz JP, Götz WS, Mandallaz D (2006). Vulnerability of spruce (Picea abies) and beech (Fagus sylvatica) to storms and consequences for silviculture. Eur J Forest Res 125:291302.

Steffenrem A, Saranpää P, Lundqvist S-O, Skrøppa T (2007). Variation in wood properties among five full-sib families of Norway spruce (Picea abies). Ann For Sci 64:799-806.

Şofletea N, Curtu L (2007). Dendrology. Ed. Transilvania University, Braşov (in Romanian).

Şofletea N, Budeanu M, Pârnuță G (2012). Provenance variation in radial increment and wood characteristics revealed by 30 years old Norway spruce comparative trials. Silvae Genetica 61(4-5):170-178.

Tahvanainen T, Forss E (2008). Individual tree models for the crown biomass distribution of Scots pine, Norway spruce and birch in Finland. For Ecol Manage 255:455-467.

Tollefsrud MM, Kissling R, Gugerli F, Johnsen O, Skrøppa T, Cheddadi R, Knaap WO, Latalowa M, Terhurne-Berson R, Litt T, Geburek T, Brochmann C, Sperisen C (2008). Genetic consequences of glacial survival and postglacial colonization in Norway spruce: combined analysis of mitochondrial DNA and fossil pollen. Molecular Ecology 17:4134-4150.

Ujvari E, Ujvari F (2006). Adaptation of progenies of a Norway spruce provenance test (IUFRO 1964/68) to local environment. Acta Silv Lign Hungary 2:47-56.

White TW, Adams WT, Neale DB (2007). Forest genetics. $\mathrm{CAB}$ International, CABI Publishing, Cambridge.

*** ANM (2011). Romanian National Meteorological Administration.

*** STATISTICA 8.0, StatSoft Inc., Tulsa, OK, USA, 2008. 